\title{
The Correlation toward Students' Vocabulary Mastery between Using Jig Saw and TGT Technique
}

\author{
Nurnalisa \\ English Department of STKIP Kumala Lampung Metro \\ E-mail: onengnurnalisa@yahoo.co.uk
}

\begin{abstract}
The reason for this examination was to find out whether, using Jigsaw and TGT techniques effectively to improve student mastery of vocabulary, there were several different effects between using Jigsaw and TGT techniques on mastery of students' vocabulary. This study uses comprehensive studies using trials, initial tests, treatments, and final tests. For the principal treatment, the most elevated score was 60 and the least score was 40 . For the second treatment, the most elevated score was 70 and the least score was 45 . In the third treatment, the most elevated score was 80 and the least score was 50 The posttest results demonstrated that in the trial class the score the most noteworthy from the main treatment to the third treatment was 100 and the most reduced score was 65 with a normal of 78. Then again, in the control class the most noteworthy score from the main treatment to the third treatment was 90 and the least score was 55 with a normal of 70.44. In light of the consequences of the examination to be considered to help students master English more easily, pleasant and without pressure. This method is intended to increase student vocabulary, if this method applies in class or outside the class. Students can feel enjoyed and interested in the material. Finally, English material will be easier, more fun and without pressure to be understood and mastered by students. So, if possible, it would be better to add time for English lessons.
\end{abstract}

Keywords: Students' Vocabulary Mastery, Jigsaw Technique, TGT Technique 


\section{INTRODUCTION}

English is an international language. The teaching and learning English should be given from elementary school. At junior high school, they should most likely talk with English language dependent on the vocabulary mastery. At senior high school, speaking ability must be more than when they are at junior high school. Infect using previous technique at junior high school and the teacher only gives base guidance's about material without knowing student ability. The students' vocabulary mastery is low, so speaking ability is low too, because the student cannot respond the material. The using technique does not balance with learning achievement.

\subsection{Definition of Vocabulary}

Vocabulary is one of important aspect in language. When everybody does not master of vocabulary, he or she cannot explain and express their ideas to other people. According to Napa (1991) states that "Vocabulary is one of the language components and three is no language without words". It is clear that vocabulary is exceptionally fundamental part in learning English, in light of the fact that the language is used for communicate. Whether it is spoken written, is made up of vocabulary. The learner cannot communicate appropriately if not master the vocabulary, but in English thee grammar is important aspect too. It cause the learner will not know the mean of the sentence without master the grammar of English. According to Lynne Cameron (2002:84) states that, "Vocabulary needs to be met and recycled at interval, in different activities, which new knowledge and new connection developed each time the same words are met again".

Technique is the work of system or group of learning that is structured. The kind of cooperative learn is applied, such as: STAD (Student Teams Achievement Division), TAI (group Assisted Individualization), TGT (Teams Games Tournament), and Jigsaw (Group Investigation). Definition Jigsaw is a helpful learning procedure proper for understudies somewhere in the range of third and twelfth grade.

The essential contrasts in agreeable learn isn't established in gathering of learning. The characteristic of cooperative learning based on Ibrahim (2000:6) is "siswa bekerja dalam kelompok secara kooperatif untuk menuntaskan materi belajarnya, kelompok dibentuk dari siswa yang berkemampuan tinggi, sedang, dan rendah".

Vocabulary also makes the learner easy to express their idea. It shows that vocabulary is important to learn beside the grammar of English. It supported in website states that, "vocabulary is the most essential aspect of language: therefore it is very important to learn vocabulary from very beginning. The students usually feel bored in vocabulary learning. So, it is needed to 
create the best way to teach it". According to Lynne Cameron (2002:84) states that, "Vocabulary needs to be met and recycled at interval, in different activities, which new knowledge and new connection developed each time the same words are met again".

\subsection{Technique}

Technique is the work of system or group of learning that is structured. The kind of cooperative learn is applied, such as: STAD (Student Teams Achievement Division), TAI (group Assisted Individualization), TGT (Teams Games Tournament), and Jigsaw (Group Investigation).

Definition Jigsaw is an agreeable learning strategy proper for understudies somewhere in the range of third and twelfth grade. In view of Lie (2002:28)," demonstrates pembelajaran kooperatif berbeda dengan sekedar belajar dalam kelompok". The basic differences in cooperative learn is not founded in group of learning. The characteristic of cooperative learning based on Ibrahim (2000:6) is "siswa bekerja dalam kelompok secara kooperatif untuk menuntaskan materi belajarnya, kelompok dibentuk dari siswa yang berkemampuan tinggi, sedang, dan rendah".

\subsection{Concept of Jigsaw Technique}

The Jigsaw Technique is a helpful learning strategy that appropriates for understudies somewhere in the range of third and twelfth grade. This methodology is a productive method for instructing material that likewise supports tuning in, commitment, association, educating, and participation by giving every individual from the gathering as a basic part to play in the scholarly action. The procedure includes breaking the classroom into little gatherings of four to six understudies. Each gathering is in charge of a particular bit of information that they will examine with different colleagues.

Elliot Aronson first developed a jigsaw approach to the classroom. Every understudy in the group had some expertise in part of the learning units, met with understudies from different groups with the comparing angle, and in the wake of acing the material came back to the group to show his/her colleagues. The first Jigsaw was created to make outrageous reliance among partners; each expert was the only one to see that part of the learning material. Although this extreme form of interdependence ensured positive relations among students, it was not practical because it involved rewriting the text (Kagan, 1994). 
The jigsaw classroom is a helpful learning system with a three-decade track record of effectively lessening racial clash and expanding positive instructive results. Similarly as in a jigsaw confound, each piece- - every understudy's part- - is basic for the fulfillment and full comprehension of the last item. On the off chance that every understudy's part is fundamental, at that point every understudy is basic; and that is correctly what makes this technique so viable.

The historical backdrop of jigsaw, jigsaw classroom was first utilized in 1971 in Austin, Texas. My alumni understudies and I had created the jigsaw procedure that year, as an issue of supreme need to help defuse a hazardous circumstance. The city's schools had as of late been integrated, and in light of the fact that Austin had dependably been racially isolated, white adolescents, African-American youths, and Hispanic youths ended up in similar classrooms out of the blue. Inside fourteen days, in length standing doubt, dread, and doubt between gatherings created a climate of strife and antagonistic vibe. Clench hand battles emitted in passages and schoolyards over the city.

\subsection{Concept of TGT Technique}

TGT (Teams Games Tournament) is one of kind of cooperative learn using media, example: picture, video, record exc. TGT is the contest of team is development of STAD. The teacher performing to contest with other team and assessment based on sum of value from every team. In view of the clarification above it very well may be presumed that method can build the soul of understudies and impact toward learning accomplishment.

TGT model of agreeable learning is one sort or model of helpful learning are anything but difficult to actualize, including all understudies with no refinement of status. This sort includes the job of understudies as friend coaches, the diversion contains components that can animate excitement for learning and contain fortification. Learning exercises with diversions that are structured in a helpful learning model enables understudies to learn TGT is progressively loose notwithstanding foster duty, trustworthiness, collaboration, sound challenge and the association of learning.

There are five primary parts of TGT, to be specific:

\section{Presentation class}

In early learning in getting ready instructors to submit classroom materials, typically done by direct educating or with addresses, dialogs driven by educators. At the season of 
introduction of this class, understudies should focus and comprehend the material given by instructors, since it will enable understudies to work better when the work gathering and at the diversion in light of the fact that the score of the amusement will decide the score of the gathering.

\section{Team (Team)}

The gathering typically comprises of four to five understudies. The capacity of the gathering is to additionally investigate the issue with companions gatherings and all the more explicitly to plan bunch individuals to work appropriately and ideally at the season of the diversion.

3.Game

Diversion comprises of inquiries intended to test understudies' information picked up from classroom introduction and study gatherings. Most amusements comprise of basic inquiries numbered. Understudies select a numbered card and attempt to address the inquiries as per the number. Understudies who accurately answer that question would get a score.

\section{Tournament}

To begin the competition each of the participants took the lottery numbers. Students who obtain the largest number as the reader 1 , the second largest as challenger 1 , the third largest as challenger 2 , the fourth largest as challenger 3 . And if the number of participants in the group of five persons, who got the lowest number as reader2. Reader is a duty to read about and answer the questions at the first opportunity. Challenger a job answering questions read by reader1 if by challenger 1 answer reader a wrong. Challenger second task is to answer the question which was read by a reader earlier if the reader answers 1 and 2 challenger one by one. Challenger third task is to answer the question which was read by the reader 1 when the answer reader1, challenger 1 , challenger 2 by challenger 3 wrong. Reader second task is to read out the answer key. The game resumed in a matter of number two. The position of the participants turned in a clockwise direction. Which had become challenger 1 now becomes reader1, challenger 2 to challenger 1,3 becomes challenger 2 , reader 2 to challenger 3 and reader 1 into reader2. It continues to do as much as the number of questions that provided teachers.

5. Award group (Team Recognize)

The teacher then announced the winning group, each team will receive a gift certificate or if the average score to meet the specified criteria.

Based on the explanation above, team game tournament (TGT) is an appropriate method with this subject. This method is one of the models cooperative learning. Cooperative Learning is an instructing course of action that alludes to little, heterogeneous gatherings of 
understudies cooperating to accomplish a shared objective) (Kagan, 1994). Understudies cooperate to learn and are in charge of their partners' learning just as their own. The essential components are:

1. Positive Interdependence - happens when increases of people or groups are emphatically related.

2. Singular Accountability - happens when all understudies in a gathering are considered responsible for completing an offer of the work and for mastery of the material to be scholarly.

3. Measure up to Participation happens when every individual from the gathering is managed equivalent offers of duty and information.

4. Synchronous Interaction - happens when class time is intended to permit numerous understudy associations amid the period.

In this exploration will take two classes for the example and the analyst will utilize group irregular examining method. As test in this examination taken is two classes, each class is consisted of 35 students must have a comprehension with two techniques and chose two classes. Using the formula of research sample by Slovin Formula, so, 32 students in experiment class A that will use Jigsaw and TGT technique. For 32 students in control class B that will use a conventional technique on the subject of vocabulary.

The procedure of the research as follows: The try out will be used before pre-test and gives for other class beside the sample gives try out test in one class with 20 students. It was performed so as to know the quality and the reverence of the classes. There are 20 items of multiple choice tests. In this case, the pre-test will be used to discover the understudy's capacity before treatment. The instance of pretest is that understudies are asked to be able to do the test and the able the characteristic of objects or events in the form of descriptive paragraph. Here, the students are assigned to describe picture that consist of 30-50 word. With time allocated for about 30 minutes.

In this research divides two classes they are experiment class and control class, treatment in 40 minutes for meeting. In the experiment class, the researcher gives three times of treatment. In the first treatment, explains the goals and the objective of instruction and also aspect vocabulary mastery, explains how to like vocabulary and the able to do test. In the second treatment of learn with using jigsaw technique to interest the students, for example, the teacher divides the students to some groups, and then the every group gives some pictures that is different, so the students describe a picture. In the third learn with using TGT technique with puzzle media. In the control class, the researcher gives three times using a conventional technique on the subject of vocabulary. The research conducts 
post-test in order to measure the increase of student's vocabulary mastery through picture and with games. The students are assigned to be able do the test; there are five aspect meaning, grammar, idiom, synonym and antonym for about 60 minutes. After scoring students work is finished, certainly compare the post-test and pre-test scores in vocabulary composition.

\section{METHOD}

The researcher is conducted by using an experimental technique. An experiment involves the cooperation of the effect of a particular treatment with that of a different treatment or of no treatment. The researcher uses two groups randomize pre-test and post-test plan. This examination applies one pre-test and one post-test in which three times of treatment is given between them. The criteria whether discuss can increase students vocabulary mastery is determined by the differences between the scores of the pre-test and post-test. The researcher uses those tents to get the data and giving treatment. The mean of the test is to find out whether students of divide to some group and with games. The researcher chose this design because any five class to research and with sampling random chose two classes and each class to consist 35 students.
The validity test the researcher uses the correlation formulation of product moment with raw scores are:

$$
r x y=\frac{N\left(\sum x y\right)-\left(\sum x\right)\left(\sum y\right)}{\sqrt{\left.\left\{N \sum x^{2}-\left(\sum x\right)^{2}\right) N \sum y^{2}-\left(\sum y\right)^{2}\right\}}}
$$

Note :

$r_{x y}=$ Correlation coefficient

$\mathrm{N}=$ Number of subject

$\mathrm{X}=$ Score of students' listening ability in each items

$\mathrm{Y}=$ Total score of students' listening ability

Value of correlation coefficient between two variables are +1 . If coefficient between two variables is zero (0), it means between two variables there is no correlation. Opposite if coefficient between two variables is +1 , it meant, the variables have perfect correlation. The high coefficient near +1 so high correlation gotten. The other words then from calculation result of interpreting the coefficient correlation according to (Arikunto, Dasar-dasar Evaluasi Pendidikan, 1991) as follow :

Between $0.800-1.000$ very high

Between 0.600-0.800 enough

Between $0.400-0.600$ fair

Between $0.200-0.400$ low

Between $0.000-0.200$ very low

The reliability test the researcher uses: 


$$
r x y=\frac{N\left(\sum x y\right)-\left(\sum x\right)\left(\sum y\right)}{\sqrt{\left\{N \sum x^{2}-\left(\sum x\right)^{2}\right)\left(N \sum y^{2}-\left(\sum y\right)^{2}\right\}}}
$$

Note:

rxy : the coefficient correlation between $\mathrm{X}$ and $\mathrm{Y}$

$\mathrm{X}$ : the score of the odd test item

$\mathrm{Y}:$ : the score of the even test item

$\mathrm{X}^{2} \quad$ : the quadrate score of the odd test item

$\mathrm{Y}^{2} \quad:$ the quadrate score of even test item

$\sum X Y$ : the score of $X$ and $Y$ product

$\mathrm{N}$ : the total number of sample

To find reliability of the test, the researcher will use the Spearman brown, the formula as follow:

$$
r i i=\frac{2\left(r_{x y}\right)}{1+r(x y)}
$$

Note:

rii : Reliability instrument

rxy : the coefficient correlation between score test

In this case the researcher also uses the criteria reliability (Arikunto, Dasardasar Evaluasi Pendidikan, 1991) bellow:

$$
\begin{array}{ll}
0.81-1.00 & =\text { very high } \\
0.61-0.80 & =\text { high } \\
0.41-0.60 & =\text { enough } \\
0.21-0.40 & =\text { low } \\
0.00-0.20 & =\text { very low }
\end{array}
$$

\section{FINDING AND DICUSSION}

The scientist gave tryout once for 20 understudies, which comprise of 20 things of decision question, in light of the fact that after determined the test has not been dependable, it implies that instrument has not substantial. Thus, the analyst must modification the test, after the amendment and after determined the test has been dependable and that instrument has substantial.

After determined by utilizing item minute equation, it was gotten 0.82 . It was the connection between's odd thing and even thing score, and afterward from the count that utilizing by spearman-dark colored equation gotten rii $=0.90$. In the event that the outcome counseling to the $r$ score, it implies that the outcome has high translation.

The pre-test was provide for 64 understudies which comprise of 20 things test. The understudies were originated from 32 understudies of VIA and 32 understudies of VIB. in trial class the most elevated score was 60 and least was 45 which had a mean 54.84. in the interim, in control class the most elevated score was 50 and least 35 which had a mean 42.65 . 
In this trial class, for the main treatment, the most elevated score was 70 , and the least score was 50. In the second treatment, the most elevated score was 80 and the least score was 55. The third treatment, the most astounding score was 90 and the least score was 60 . The all out score of the principal treatment until the third treatment in exploratory class was 6950 with the mean 217.18.

In other hand, in charge class the all out score of the main treatment until third treatment was 5750 with the mean 179.68. For the primary treatment, the most astounding score was 60 and the least score was 40. For the second treatment, the most elevated score was 70 and the least score was 45. In the third treatment, the most astounding score was 80 and the least score was 50.

In trial class the most elevated score of the primary treatment until third treatment was 100 and the least score was 65 with the mean 78 . In other hand, in charge class the most astounding score of the principal treatment until third treatment was 90 and the least score was 55 with the mean 70.44 .

It demonstrated that L-proportion in trial class got 10.63 and in control class got 6.96. Either on hugeness level 0.05 or $0.01 \mathrm{~L}$-proportion is lower than L-table. In this way, both of classes had ordinary dispersion.

The outcome was homogeneous; from the post-test demonstrated F- proportion was 1.2. On hugeness level 0.05 or 0.01 , Fval < Ftab. Along these lines, Ho acknowledged or at the end of the day the two populaces had same difference or homogeneous.

On criticalness level 0.05 or 0.01 was 2.00 and 2.66. In light of the criteria above, Ho is rejected and $\mathrm{Ha}$ is acknowledged. It implies that, there is huge contrast in understudy's vocabulary dominance between understudies who are educated by jigsaw method and who are instructed by TGT system, and TGT strategy was increasingly successful or equivalent to jigsaw procedure to use in vocabulary for the seventh grade understudies in SMP N 1 Batanghari.

In this exploration, in exploratory class and control class was treated for three gatherings. For the trial class was instructed through TGT strategy and control class was educated through jigsaw procedure. This examination demonstrated that there is an alternate score from the investigation class and control class.

The information which depicted in this examination are the information of the comparison of jigsaw technique and TGT technique in vocabulary mastery between the experimental class and control class.

After given the medicines until last gathering, they understood that method can assist them with mastering the vocabulary less demanding and charming. Researcher made 
understudies mindful that English isn't so hard to be aced.

In experiment class, in game, students enjoyed what they doing. For pre-test, it was gained the data that the most astounding score was 60 and least was 45 which had a mean 54.84. At the point when researcher gave the medications it was picked up; in the principal treatment, the most astounding score was 70, and the least score was 50 . In the second treatment, the most elevated score was 80 and the least score was 55. The third treatment, the most noteworthy score was 90 and the least score was 60. At that point in post-test, it was gotten the most elevated score was 100 and the least score was 65 with the mean 78. From the information, it was demonstrated that they had an expansion in vocabulary, to be specific from 54.84 to 78 .

It was also occurred in control class. When the students divide to some group and give different sub material in every group, actually some of the students were interested and focus to the material. They felt very enjoy without any pressure in their study, but their interest not bigger than experimental class. In this class, for pretest researcher gained the data that the most elevated score was 50 and least 35 which had a mean 42.65. Then they were given treatments by researcher.

In the primary treatment, the most elevated score was 60 and the least score was 40. For the second treatment, the most noteworthy score was 70 and the least score was 45 . In the third treatment, the most noteworthy score was 80 and the least score was 50. At that point in post-test, it was picked up the most noteworthy score of the principal treatment until third treatment was 90 and the least score was 55 with the mean 70.44 . From the data, it was also shown that the students in control class had an increase in vocabulary too. Their increasing was shown from 42.65 to 70.44 .

Based on the finding, for junior high school students, in their ages, they still felt difficult to understand the meaning of English words. There, teacher should be patient in learning process; teacher must translate word by word until it could be understood by students. Moreover, when they face new word to fit the intended meaning, it will make them frustrating when the teacher only asks them to memorize the word.

The researcher found, there was not happening enlargement of the explanation when the vocabulary was accruing. The game and group it made high concentration of them. So, the teacher could be saved their power when they taught the students.

Based on the statement and the experience when conducting the research, the researcher found that the jigsaw technique and TGT technique could make the students enjoy and 
comfort in vocabulary mastery. Then, according to the result of this research, it concluded that there was a significant difference between vocabulary mastery by using jigsaw technique and TGT technique for the students in seventh grade in SMP N 1 Batanghari.

This research was conduct with give three treatments for the students in $\mathrm{VI}^{\mathrm{B}}$ as experiment class and $\mathrm{VI}^{\mathrm{A}}$ as control class. Each of the classes was given the same material with different method to transfer the vocabulary subject. After giving the pre-test, treatments and post-test for them, researcher got the data which had shown that there was significant difference between jigsaw technique and TGT technique.

From the data, researcher also found that the students who taught by using TGT technique had score higher than students that taught by using jigsaw technique. It was proved from total treatments score in experiment class was 6950 with the mean 217.18, and for post-test mean score was 78 . Meanwhile in control class who taught by using jigsaw technique had a total treatments score 5750 with the mean 179.68 , and post-test mean score was 70.44 .

In experiment class, researcher gave the game. The students divide into some group and every group has book and dictionary. They were song together with around the book and dictionary and if finish the song who bring the book and dictionary must answer the question from the researcher. So, they were very interest to follow the study. The material transferred was easy to receive by them. In control class, researcher divides into some group and every group given some different picture and they must describe the picture. After that they were present in front of class. In fact, based on the researcher's experience along conduct the research, there is difference response between experiment class and control class in receiving the subject. Experimental class was more interesting to follow study by using TGT technique than control class who taught by using jigsaw technique, because of that, in this research it was found that TGT technique was more effective to teach vocabulary than jigsaw technique.

It means that giving and teaches for the students by using jigsaw and TGT technique is different, because they have deferent type in learning and when they accept the information from the teacher. So, from the data, it could said that TGT technique had more effective or equal to jigsaw technique in vocabulary mastery for the students in junior high school, especially in SMP N 1 Batanghari.

\section{CONCLUSION}

Based on the compare of the look at toward understudies' vocabulary mastery using jigsaw and TGT strategy. TGT Technique toward understudies' Vocabulary Mastery. The 
understudy's vocabulary had expanding in learning process. It was all the more intriguing to pursue think about by utilizing TGT method. From the aftereffect of this exploration that has portray and more talked about, specifically in test class, for pre-test, it was picked up the information that the most astounding score was 60 and least was 45 which had a mean 54.84. At the point when gave the medicines it was picked up; in the principal treatment, the most noteworthy score was 70, and the least score was 50. In the second treatment, the most astounding score was 80 and the least score was 55 . The third treatment, the most astounding score was 90 and the least score was 60. At that point in post-test, it was gotten the most elevated score was 100 and the least score was 65 with the mean 78. From the information, it was demonstrated that they had an expansion in vocabulary, to be specific from 54.84 to 78 .

Jigsaw system toward understudies' vocabulary mastery. In this control class, for pretest scientist picked up the information that the most elevated score was 50 and least 35 which had a mean 42.65. At that point they were given medicines by scientist. In the principal treatment, the most astounding score was 60 and the least score was 40. For the second treatment, the most noteworthy score was 70 and the least score was 45 . In the third treatment, the most elevated score was 80 and the least score was 50. At that point in post-test, it was picked up the most elevated score of the primary treatment until third treatment was 90 and the least score was 55 with the mean 70.44 . From the information, it was likewise demonstrated that the understudies in charge class had an expansion in vocabulary as well. Their expanding was appeared 42.65 to 70.44 .

1. The Result Learning by Using Jigsaw and TGT Technique.

From the data, researcher presumed that there was critical contrast of utilizing jigsaw system and TGT strategy in vocabulary dominance for the seventh understudies in SMP N 1 Batanghari. In test class was 6950 with the mean 217.18. In control class who instructed by utilizing jigsaw strategy had a complete medicines score 5750 with the mean 179.68. The, it was discovered that TGT procedure had increasingly compelling or equivalent to jigsaw method in vocabulary mastery for the understudies in middle school s1chool, particularly in SMP N 1 Batanghari. It was demonstrated from the post-test information that in analysis class, it had post-test mean score 78 and in control class, it had mean score 70.44 .

Jigsaw and TGT system as strategy in vocabulary mastery had commitment and noteworthy impact for the two understudies and instructor. The understudies delighted in and they were fun in tolerating data particularly the new involvement in learn 
vocabulary, while the instructor was less demanding in exchanging material to learn vocabulary. In addition, the understudies increasingly comprehended about vocabulary have a place with its markers. Thus, they could compose and talk better than anyone might have expected.

Jigsaw method and TGT system has compelling to use as media to exchanging vocabulary material for the understudies grade seventh, despite the fact that they have distinctive in understudies accomplishment.

\section{REFERENCES}

Arikunto, S. (1991). Dasar-dasar evaluasi pendidikan. Jakarta: rineka.

Arikunto, S. (1991). Dasar-dasar evaluasi pendidikan. Jakarta: Bumi Aksara.

Austin, Texas. 1971. Hisstory of jigsaw, Overview of Technique. http://www.jigsaw.org/history.h tm. Accessed on Monday, July 9, 2018 at 3.50 PM

Kagan, S. (1994). Cooperative Learning San Clemete. California: Kagan Publishing.

Lynne Cameron. 2002. Vocabulary need to be met and recycled at interval, in different activities. States. http://library.gunadarma.ac.id. Accessed on Friday, June 1, 2018

Napa, Pieter, A. 1991. Vocabulary Development Skill. Jakarta: Yayasan Kanisiles.

Napa. 1991. Vocabulary is one of the language components and three is no language without words. States. http://library.gunadarma.ac.id. Accessed on Saturday June 2, 2018 at $9.25 \mathrm{PM}$

Sudijono, Drs.Anas. 2001. Pengantar Statistic Pendidikan. Jakarta: PT. Raja Grafindo Persada. 